\title{
Changes of American Foreign Policy towards the Countries of the Former Yugoslavia between 1991 and 1995
}

\section{Lukáš VOMLELA}

\author{
Ústav středoevropských studií, Fakulta veřejných politik, Slezská univerzita v Opavě \\ Institute of Central European Studies, Faculty of Public Policies, Silesian University in Opava \\ Bezručovo nám. 885/14, 74601 Opava, The Czech Republic \\ lukas.vomlela@fvp.slu.cz
}

\section{Introduction}

The process of disintegration of Yugoslavia was related to the geopolitical changes in the region of Central and Eastern Europe, and the war that took place in the former Yugoslavia was one of the major armed conflicts on the European continent after the Cold War. At first the conflict had an internal character, but with the declaration of independence of Slovenia and Croatia in connection with international recognition of individual Yugoslav republics, which declared independence, the conflict gained international character. ${ }^{1}$ The United States were a significant actor who played a key role in the development, progress and the very end of the war in the former Yugoslavia between 1991-1995. The effect of American diplomacy was very fluid at that time and it changed in response to changes in the international world order after the end of the Cold War, which also related to the status of Yugoslavia as one of the main beneficiaries of the former bipolar structure. ${ }^{2}$ While during the Cold War the position of Yugoslavia was quite significant in international relations and for the United States the Yugoslav Federation was one of the major partners, in the late 80s its position considerably weakened.

Earlier significance of Yugoslavia was mainly caused by a significant departure of Yugoslav Communists from the Soviet Union, the progressive introduction of the model of self-management socialism that for other communist countries could mean some alternative, and also by its strategic location, given by proximity to the NATO member states and of the Warsaw Treaty Organization, too. ${ }^{3}$ The prestige of Yugoslavia was also reinforced by its significant engagement in the Non-Aligned Movement. The status of Yugoslavia also changed in connection with changes in the USSR after the arrival of Mikhail Gorbachev's and the policies of Glasnost and Perestoika. Yugoslavia gradually lost its importance for both the United States and the Soviet Union. ${ }^{4}$ Changes in the international environment prompted the United States to reconsider its foreign policy priorities, while relations with Yugoslavia and American attitudes towards the Yugoslav crisis were developing in a very complicated

1 BUJDWID-KUREK, Ewa: Państwa pojugosłowiańskie. Szkice politologiczne. Kraków 2008, 56.

2 ZACHARIAS, Michał Jerzy: Komunizm, federacja, Nacjonalizmy: System władzy w Jugosławii 1943-1991.

Powstanie - prezekształcenia - rozkład, Warzawa 2003, 542.

3 Ibidem.

4 Ibidem. 
way and were subject to significant changes in terms of American involvement, measure of interest and the strategy itself against particular Yugoslav participants and later also against belligerents in the Yugoslav conflict. ${ }^{5}$ International community, including the United States, did not have a clear strategy at the beginning of the Yugoslav crisis and after the outbreak of the war, it hesitated and sought for possible solutions that were difficult to find for a long time. ${ }^{6}$

The article wants to contribute to the understanding of key factors that led to the extensive conflict in the former Yugoslavia as well as the factors that influenced its progress. The theme of breakup of Yugoslavia and the subsequent conflict is captured fairly well in contemporary literature. Yet, there is still an ongoing reflection on particular events and phenomena which offer new and often interesting views on a wide range of aspects that had been neglected before. The article is focused on the international community's reaction to events in the former Yugoslavia between 1991-1995 and, in particular, on the changes of the United States foreign policy with regard to the dynamics of the conflict, and it tries to set factors which determined its attitude to the breakup of Yugoslavia and the ongoing conflict. Therefore, the article tries to give more detailed description of all sides involved in the conflict, paying attention to their strategies, major requirements and objectives. It also tries to determine to what extent U.S. strategy in 1995 was successful.

\section{Process of Disintegration of Yugoslavia}

After 1945, Yugoslavia went through a difficult and complicated political development, and the tendencies of disintegration, which were strongly manifested mainly in the 80s and which resulted in its breakup in the early 90s, had a long-term character. The problems Yugoslavia faced, could also be seen in frequent changes in the constitutional order. According to Jelena Guskova "no other country has instituted so many reforms, changes in economic and political system, nor has accepted so many constitutions and their amendments. ${ }^{17}$ The constant need to prevent ethnically motivated unrest in multiethnic Yugoslavia, as well as efforts to introduce constituents of the so-called self-management socialism after the split between the Soviet Union and Yugoslavia at the end of the 40s of the $20^{\text {th }}$ Century were the two central themes of numerous revisions and interventions in the Yugoslav constitutions and laws.

In 1974, the last valid constitution of the Socialist Federal Republic of Yugoslavia (SFRY) was accepted, which in addition to the possibility of life election of president Josip Broz Tito confirmed the complicated decision-making mechanisms requiring consensus of representatives of particular republics and autonomous provinces, which was rather problematic to achieve mainly in the 80 s. Consociational mechanisms established at national level in the particular republics and autonomous provinces were missing, ${ }_{1}^{8}$ and this absence was heavily reflected in the process of transition and subsequent disintegration of the multieth-

5 JOKSIMOVIĆ, Aleksandra: Srbija i SAD. Bilateralni odnosi u tranziciji. Beograd 2007, 29.

6 Ibidem.

7 GUSKOVA, Jelena: Istorija jugoslovenske krize (1990-2000)1, Beograd 2003, 71.

8 VLADISAVLJEVIĆ, Nebojša: Serbia's Antibureaucratic Revolution. Milošević, the Fall of Communism and Nationalist Mobilization, New York 2008, 36. 
nic confederation. After the death of Josip Broz Tito in 1980, the problems of the Socialist Federal Republic of Yugoslavia became much more intensive. Due to totally different political concepts in particular League of Communist, ${ }^{9}$ consensus on another strategy towards a deepening economic crisis, the problems of internal organization and the relations between the Federation and its republics and autonomous provinces was difficult to find. ${ }^{10}$ Relations became even more complicated after the democratic elections that were held in the republics in 1990 and were won by totally different political parties. In Slovenia, government was formed by parties grouped in the coalition of Democratic Opposition of Slovenia (Demokratska opozicija Slovenije, DEMOS). In neighbouring Croatia, the victory went to a coalition of parties led by the Croatian Democratic Union (Hrvatska demokratska zajednica, HDZ), with Franjo Tudjman as a chairman. In Serbia and Montenegro post-communist parties of succession won and were able to form independent governments on the level of a republic. Serbian political scene was dominated by the Socialist Party of Serbia (Socialistička partija Srbije, SPS), whose chairman Slobodan Milosević was elected in direct presidential elections. In Macedonia, despite considerable electoral gain of $42 \%$ of votes, the strongest party VMRO-DPMNE ${ }^{11}$ remained in opposition, while the government majority was formed by left-wing parties led by post-communists. In 1990, in national elections in Bosnia and Herzegovina $(\mathrm{BiH})$ ethnic parties significantly succeeded reflecting ethnic composition of the population. ${ }^{12}$ It was Alija Izetbegović's Party of Democratic Action (Stranka demokratske akcije, SDA) that received the highest number of votes, the second strongest party was the Serb Democratic Party (Srpska demokratska stranka, SDS) led by Radovan Karadžić, and the third place was taken by Croatian Democratic Union of BiH (Hrvatska demokratska zajednica Bosne i Hercegovine, HDZ-BiH). ${ }^{13}$ Initially, these parties cooperated in Bosnia and Herzegovina, but the situation was soon changed at the turn of 1991 and 1992 in connection with the process of disintegration of Yugoslavia.

\section{U.S. Attitude towards Breakup of Yugoslavia}

In 1989, Warren Zimmermann was appointed the U.S. ambassador in Yugoslavia, and he stated that his work had been mainly determined by new U.S. attitude to the countries of Central and Eastern Europe being in the democratization process, and he had showed Yugoslav political elites that "Yugoslavia no longer enjoyed geopolitical importance that

9 Each republic and autonomous region had its own party organization, the members of the League of Communists of Vojvodina and the League of Communists of Kosovo were also members of the League of Communists of Serbia, and could thus participate in inner-party decision-making process there. Yugoslav People's Army had its own League of Communists, too. See Lukáš VOMLELA, Svaz komunistů Srbska v procesu tranzice a dezintegrace Jugoslávie, Opava 2013, 50.

10 PIRJEVEC, Jože: Jugoslávie 1918-1992 - Vznik, vývoj a rozpad Karadjordjevićovy a Titovy Jugoslávie, Praha 2000, 424-425.

11 Internal Macedonian Revolutionary Organization - Democratic Party for Macedonian National Unity.

12 According to Yugoslav census in 1991, the Muslims were the largest nation with $43 \%$ of population of Bosnia and Herzegovina, the Serbs were $31.4 \%$ and $17.3 \%$ were Croats. See ОБРАДОВИЋ, Жарко: Манине на Балкану, Београд 2002, 432.

13 GOATI, Vladimir et al.: Jugoslavija na prekretnici. Od monizma do gradjanskog rata, Beograd 1991. 
the United States had given it during the Cold War." ${ }^{14}$ At that time, the key issues for the United States were human rights, civil liberties and democratization, determining American attitudes to particular countries of the region. In this context Warren Zimmermann admitted that "Yugoslavia's record on that issue was not good - particularly in the province of Kosovo." 15 Loss of the privileged position and the interest of countries of Western Europe and the United States Yugoslavia had enjoyed until then, also meant the closure of financial loans which were very important for Yugoslav economy during the Cold War. ${ }^{16}$

The United States and Western Europe were also aware of the possible danger of destabilization of Central and Eastern Europe, which could have been further intensified by the threatening breakup of Yugoslavia. There was a risk of spreading the disintegration tendencies into some parts of the Soviet Union and which could result in a breakup of Czechoslovakia. ${ }^{17}$ Increasing concerns about political stability in this area were also a major motive for U.S. foreign policy to declare openly their support for the unity and integrity of Yugoslavia, but only in the context of democratization changes. ${ }^{18}$ In the last years of the Socialist Federal Republic of Yugoslavia, the United States primarily focused on supporting Ante Marković, the reform federal Prime Minister, who was a strong alternative for the leaders in particular republics. American diplomacy also tried to gain support for him in the countries of Western Europe. ${ }^{19}$ On 21 June 1991, several days before declaring independence in Slovenia and Croatia, James Baker, U.S. Secretary of State, arrived in Belgrade. His mission, however, lacked a specific vision and had only a "few ideas to offer on Yugoslavia except to suggest that the U.S. wanted a united and democratic Yugoslavia." 20 His journey wanted to give a clear signal that the international community would tolerate neither unilateral declarations instead of dialogue nor the use of force. ${ }^{21}$ During the day he met leaders of Kosovo Albanians, representatives of the particular republics, as well as Budimir Lončar, Minister of Foreign Affairs of Yugoslavia, and the Prime Minister Ante Marković even twice. ${ }^{22}$ Baker later described that his "stay in Belgrade was one of the most frustrating and exhausting moments of his career of a foreign minister." 23 The failure of the James Baker's mission to ease the growing tension and also Baker's scepticism about further political development gradually led the U.S. administration to the decision to leave the initiative to the European Community (EC). ${ }^{24}$ According to Živorad Kovačević, the former ambassador of Yugoslavia in the U.S., this decision had severe consequences arising from the fact that the European

14 ZIMMERMANN, Warren: The Last Ambassador. A Memoir of the Collapse of Yugoslavia, in: Foreign Affairs, $74,1995,2,2$.

15 Ibidem.

16 PRTINA, Srdjan: Přeměna Jugoslávské lidové armády na armádu Srbskou, in: Mezinárodní vztahy, 40, 2005, 4,58 .

17 ZACHARIAS, 546.

18 ZIMMERMANN, 3.

19 Ibidem, 6.

20 KLEMENČIĆ, 192.

21 ZACHARIAS, 567.

22 ZIMMERMANN, 11.

23 ZACHARIAS, 570.

24 KOVAČEVIĆ, Živorad: Amerika i raspad Jugoslavije, Beograd 2007, 155. 79. 
Community was not sufficiently integrated and ready to find a solution of the Yugoslav crisis at that time. ${ }^{25}$

\section{Road to War}

The final act of breakup of Yugoslavia was preceded by eventual declarations of independence of the Yugoslav republics. Based on previously realized referenda, Slovenia and Croatia declared independence on 25 June 1991. ${ }^{26}$ In Macedonia, a referendum was held on 8 September 1991, in which $95 \%$ of participants agreed with establishment of sovereign Macedonia. On 17 September Macedonian parliament adopted the referendum results. On 19 December 1991, Macedonian parliament approved a declaration requiring international recognition of independence of the Republic of Macedonia. ${ }^{27}$ The most complicated process occurred in the ethnically mixed Bosnia and Herzegovina. A referendum on independence, which took place on 29 February and 1 March 1992, was boycotted by the Serb Democratic Party, which invited Bosnian Serbs not to participate. Secession of Bosnia and Herzegovina was unacceptable for this party so it tried hard to keep Bosnia and Herzegovina as parts of Yugoslavia. $63.4 \%$ of voters were in favour of independence and, despite the boycott by Bosnian Serbs, the results of the referendum were valid. ${ }^{28}$ In response to the disintegration process parliaments of Serbia and Montenegro ratified the establishing of the Federal Republic of Yugoslavia on 27 August 1992. The newly adopted constitution proclaimed legal continuity of the Socialist Federal Republic of Yugoslavia and enabled other territories to be annexed. ${ }^{29}$

After Slovenia and Croatia had declared their independence, the U.S. administration emphasized its opinion and the decision not to recognize the independence of the Yugoslav republics with respect to the imminent conflict, which could not do without acts of violence, according to it. ${ }^{30}$ Vasil Tupurkovski noted that the disunity of European countries and the "lack of common, specific European policy towards Yugoslavia meant broadcasting of different, often contradictory signals ... In many cases, these signals caused diverse and contradictory reactions, which contributed to further escalation and deepening of the crisis in Yugoslavia." ${ }^{11}$ Some Yugoslav people involved, especially Slobodan Milošević, did not much understand changes in both international political environment and attitudes of various people involved during the Yugoslav crisis. According to Aleksandra Joksimović, president of Serbia Slobodan Milošević, often "put particular signals from the international community into a misleading context and came up with inadequate conclusions". ${ }^{32} \mathrm{He}$ did not count with "loss of Yugoslavia's importance and supposed that the international com-

25 KOVAČEVIĆ, 80.

26 ŠESTÁK, Miroslav - TEJCHMAN, Miroslav - HAVLÍKOVA, Lubomíra - HLADKÝ, Ladislav - PELIKÁN, Jan: Dějiny jihoslovanských zemí. Praha 1998, 582.

27 RYCHLÍK, Jan - KOUBA, Miroslav: Dějiny Makedonie, Praha 2003, 253-255.

28 ŠESTÁK - TEJCHMAN - HAVLÍKOVÁ - HLADKÝ - PELIKÁN, 630.

29 Ibidem, 592-593.

30 KOVAČEVIĆ, 85.

31 ZACHARIAS, 559.

32 JOKSIMOVIĆ, 29. 
munity would in fact be forced to recognize any changes in Yugoslavia". "A unilateral decision made by the Federal Republic of Germany on 23 December 1991 was a turning point in the course of events. It was the decision to recognize the independence of Slovenia and Croatia, regardless of the attitudes of the other EC countries, ${ }^{34}$ which greatly influenced the attitudes of those countries in the future.

The European Community established Badinter Commission, which, in January, issued a recommendation to recognize only Slovenia and Macedonia. The committee did not recommend the recognition of Croatia due to problematic relations of Croatian political representation towards ethnic minorities, especially the Serbs, and it admitted that only after the adoption of necessary measures to strengthen the rights of ethnic minorities, a reconsideration of the statement would be possible later on. The European Commission recognized the independence of Slovenia and Croatia on 15 January 1992, and also confirmed the validity of the borders of those republics. ${ }^{35}$ The process of recognition of Macedonia was complicated by the negative attitude of Greece, which blocked the effort of the EC.

There was a relatively high risk of escalation of the conflict in Yugoslavia which had been caused by several factors. The Bush administration knew that in case of a breakup, they would not be able to do without war. ${ }^{36}$ The dynamics of the conflict on the territory of former Yugoslavia was much influenced by the Yugoslav People's Army (Jugoslovenska Narodna Armija, JNA), which was subject to federal authorities. Despite earlier efforts at a fair representation of ethnic groups among officers, they were ethnic Serbs coming from different parts of Yugoslavia who maintained dominance among officers. In the 80 s, Serbs formed approximately $63.2 \%$ of the population, which made its submission to the Serbian political leaders in the early 90 s easier. ${ }^{37}$ Although JNA was withdrawing from the territory of Bosnia and Herzegovina in April 1992, a part of the armed forces remained in the republic. It is estimated that approximately eighty thousand military personnel went over into the newly formed Bosnian Serb Army. ${ }^{38}$ In addition to JNA, the so-called Territorial Defence units were set up at the same time, which were subject to particular republics. ${ }^{39}$ Also a variety of paramilitary formations, which relatively quickly engaged in the conflict, quickly formed at the same time. Their formation was accelerated thanks to a relatively easy access to weapons. In the early 90 s of the $20^{\text {th }}$ Century, 1.1 million legal gun owners were registered in Yugoslavia and the number of unregistered holders was estimated between 1 million and 6 million. ${ }^{40}$

33 Ibidem, 29-30.

34 ŠESTÁK - TEJCHMAN - HAVLÍKOVÁ - HLADKÝ - PELIKÁN, 582.

35 Ibidem, 582

36 GOMPERT, David: How to Defeat Serbia, in: Foreign Affairs, 73, 1994, 4, 33.

37 Other nations were represented as follows: Croats 12.6\%, Macedonians 6.3\%, Montenegrins $6.2 \%$, Slovenes $2.8 \%$, Muslims $2.4 \%$. The Yugoslav nationality was claimed by $3.6 \%$ of the officer corps. PRTINA, Premèna..., 55-56.

38 THOMAS, Robert: Serbia under Milošević. Politics in the 1990s. London 2000, 121.

39 Division of the armed forces of Yugoslavia resulted from its defense doctrine that combined two methods of defense in case of attack. While all parts of the Yugoslav People's Army were intended to be engaged in the frontline war, Territorial Defense (TO) were supposed to complete its activities meant to engage guerrilla warfare. Members of these units were recruited from the local population. See PRTINA, Přeměna..., 53.

40 ANDJELIĆ, Neden: Bosnia - Herzegovina. The End of a Legacy, London 2003, 193. 
Escalation of the conflict forced American diplomacy to change their attitude to particular Yugoslav republics. Apart from several days of fighting in Slovenia, ${ }^{41}$ the conflict also escalated in Croatia, where numerous Serb minority lived. Its political leaders, represented primarily by the Serb Democratic Party (Srpska demokratska stranka, SDS), demanded annexation of areas inhabited by Croatian Serbs to Serbia even before the declaration of independence in Croatia. These discontinuous territories were later declared Republic of Serbian Krajina. ${ }^{42}$ In August 1991, the European Community successfully proposed that UNPROFOR peacekeeping forces should be placed at the demarcation line between the units of the Republic of Serbian Krajina and those of Croatia. ${ }^{43}$

After the declaration of independence in Bosnia and Herzegovina, the United States focused on its support and decided to provide prompt international recognition of Bosnia and Herzegovina. As a compensation, the United States of America offered the European Community its recognition of Slovenia and Croatia. ${ }^{44}$ The change in American opinion was due to fears of an increase in the intensity of the conflict and its exacerbation. The U.S. attitudes towards the Yugoslav crisis were influenced by American public opinion as well as ethnicity of some senators and congressmen to some extent. ${ }^{45}$ Especially Democrats expressed their support for particular republics and required better action readiness of American administration. ${ }^{46}$ In his election campaign, Bill Clinton criticized Republican administration headed by President George Bush for the USA being inactive. ${ }^{47}$

The events in Yugoslavia were considerably overshadowed by the war in the Gulf, where the United States were also engaged militarily. Bush's administration was aware of the risk connected with direct military intervention, ${ }^{48}$ therefore American foreign policy had been focusing mainly on diplomatic tools, through which it had been trying to prevent further escalation of the conflict. On 25 September 1991, UN Security Council Resolution 713 was adopted. It established an embargo on arms export to countries of the former Yugoslavia, ${ }^{49}$ which was violated during the war. Marek Waldemberg states that between April 1992 and April 1994, "Croats were delivered weapons worth 660 million USD, Serbs worth 476 million and Muslims worth 162 million". ${ }^{50}$ Because of the reluctance of the Federal Republic of

41 There were ten days of fights in Slovenia and 45 victims: 39 members of the Yugoslav People's Army and 6 members of the units subject to the leaders of Slovenia after Brioni agreement, which was arranged by the European Community, the JNA were supposed to withdraw from the territory of Slovenia, which promised to postpone its secession from Yugoslavia for three months. See ŠESTÁK - TEJCHMAN - HAVLÍKOVA - HLADKÝ - PELIKÁN, 579.

42 PRTINA, Srdjan: Zahraniční a bezpečnostní politika Srbska a Černé Hory, in: Zahraniční a bezpečnostní politika vybraných zemí Balkánu, STÝSKALíKOVÁ, Věra - SMEJKAL, Hubert (eds.), Brno 2004, 16.

$43 \mathrm{Ibidem}$. Other proposals relating to the agreement between the Republic of Serbian Krajina and Croatia were unsuccessful. See PRTINA, Zahraniční a bezpečnostní..., 16.

44 GOMPERT, 37.

45 KLEMENČIĆ, 191.

46 KOVAČEVIĆ, 72-74.

47 WALDEMBERG, Marek: Rozbicie Jugosławii. Jugosławskie lustro międzynarodowej polityki, Warszawa 2005, 182.

48 GOMPERT, 39.

49 GUSKOVA, Jelena: Istorija Jugoslovenske krize (1990-2000) 2, Beograd 2003, 21.

50 WALDEMBERG, 171. 
Yugoslavia to withdraw JNA units from Bosnia and Herzegovina and in an effort to prevent it from entering direct military fighting in Bosnia and Herzegovina, economic sanctions, based on UN Security Council Resolution 757 of May 1992, were imposed against the Federal Republic of Yugoslavia. ${ }^{51}$ The change in the US attitudes was also caused by the support that Bosnia and Herzegovina received from the governments of Egypt, Turkey and Saudi Arabia. These countries demanded active policy and intervention from the United States. ${ }^{52}$ Apart from Bill Clinton's victory in the presidential election, and influences of major Near East countries, a change in attitudes of American diplomacy was also caused by changes in domestic public opinion. ${ }^{53}$ All these factors forced the U.S. administration of Bill Clinton to be much more committed and the role of the United States gradually increased in the years to come.

At first, Bill Clinton's administration ${ }^{54}$ paid greatest attention mainly to domestic policy during his first period in office, whereas it was disunited as to foreign policy issues. As regards the question of the extent to which the U.S. should be involved with overcoming the conflict in Bosnia and Herzegovina, "vice president Gore, Anthony Lake, Gore's National Security Advisor Leon Fuerth, and then U.S. Ambassador to the UN Madeleine Albright pushed for the 'lift and strike' approach (which meant sending of arms shipments to Sarajevo Bosniak government), while threatening air strikes. The rest of the administration, especially Warren Christopher, Secretary of State, Secretary of Defence Leslie Aspin, Jr., and Collin Powell chairman of the Joint-Chiefs-of Staff, opposed this approach." 55 Changes in attitudes towards the conflict in Bosnia and Herzegovina were also becoming apparent in Europe. German foreign policy, which had been relatively active at first, eventually abandoned further initiative for Great Britain and France. These two countries, also including Spain, made a huge contribution to the UNPROFOR mission in Bosnia and Herzegovina, premediating their strong position for negation attempts at solving the conflict. ${ }^{56}$ Whereas Great Britain and France considered the conflict to be an ethnic-based civil war, Clinton's administration regarded it as an act of aggression of Serbia against Bosnia and Herzegovina, and to some extent as an act of aggression on the side of Croatia, too. ${ }^{57}$ "Therefore USA started to search for a possible solution that would include lifting the embargo on buying weaponry for the Muslims and having NATO airplanes enforce no-fly zones in $\mathrm{BiH}^{\prime 58}$ which were introduced by UN Security Council Resolution 781 from 2 September 1992.59

51 GUSKOVA, Istorija Jugoslovenske krize (1990-2000) 2, 39-40.

52 WOODWARD, Susan L.: Balkan Tragedy. Chaos and Dissolution after the Cold War, Washington $1994,296$.

53 WALDEMBERG, 184.

54 KOVAČEVIĆ, 103.

55 KLEMENČIĆ, 198.

56 KOVAČEVIĆ, 105.

57 Ibidem, 104

58 KLEMENČIĆ, 198.

59 United Nations, Security Council Resolution 781, online: http://www.un.org/en/ga/search/view_doc.asp?symbol=S/RES/781(1992). 


\section{Peace Proposals}

A series of peace proposals that were adopted during the war in Bosnia and Herzegovina were rejected by the warring sides for various reasons. On 2 January 1993, under the auspices of the UN and the EU, Vance-Owen peace plan was proposed. It suggested division of Bosnia and Herzegovina into 10 cantons whose main authorities were supposed to have fairly broad powers. Bosnian Croats and, after further negotiations, Alija Izetbegović agreed to the plan. After further discussions and partial modifications even Slobodan Milošević accepted the proposal, especially in fear of further increase of economic sanctions against the Federal Republic of Yugoslavia. ${ }^{60} \mathrm{In}$ an attempt at an increased pressure on the political representatives of the Republika Srpska, UN Security Council adopted Resolution 816 on 31 March 1993 which made it possible to enforce no-fly zones in Bosnia and Herzegovina and on the basis of which the NATO launched Operation Deny Flight on 12 April 1993. ${ }^{61}$ However, the plan was refused in Republika Srpska's referendum held on 15 and 16 May $1993 .{ }^{62}$

Another peace proposal was introduced in 1993. The Oven-Stoltenberg peace proposal was based on an idea of ethnic division of Bosnia and Herzegovina into a free confederation of three republics. Sarajevo was supposed to be under temporary UN administration and Mostar, along with other enclaves, under temporary administration of the European Union. This plan was later rejected by the leaders of the Bosnian Serbs and the Muslims. ${ }^{63}$ Another change and the need of resolute U.S. actions was caused by the massacre at Sarajevo's Markale market. 68 people died there on 5 February 1994. ${ }^{64}$ Public opinion in communities particularly in Western Europe and North America was struck by this incident. After the request of the UN Secretary General Boutros Boutros Ghali, the political representation of Bosnian Serbs was given an ultimatum by the NATO Council, which demanded Bosnian Serb Army to be withdrawn as far as $20 \mathrm{~km}$ from Sarajevo and heavy weapons to be removed. To prevent refusal, a threat of NATO air strikes against the positions of the Republika Srpska was used. ${ }^{65}$

In March 1994, American diplomacy achieved great success after they had arranged an agreement between Franjo Tudjman and Alija Izetbegović, which stopped fights between Bosniaks $^{66}$ and Bosnian Croats, and on the basis of which Federation of Bosnia and Herzegovina was established. ${ }^{67}$ By this step, a bloc of both sides against the Bosnian Serbs

60 PRTINA, Zahraniční a bezpečnostní..., 21-23.

61 KLEMENČIĆ, 200.

62 PRTINA, Zahraniční a bezpečnostní..., 23.

63 Ibidem, 24.

64 ŠESTÁK - TEJCHMAN - HAVLÍKOVÁ - HLADKÝ - PELIKÁN, 636.

65 Ibidem. Bosnian Serb positions were bombed twice in the second half of 1994. It was an airstrike against their positions around Sarajevo and those near the town of Bihać in Western Bosnia. See WALDEMBERG, 175.

66 In September 1993, Bošnjački Sabor met, which was attended by 350 Muslim political and religious leaders in Bosnia and Herzegovina. Among other things, there was decided to adopt a new name "Bosniaks", which was to replace the original, formerly used term "Muslims" for members of this nation. See ŠESTÁK - TEJCHMAN HAVLÍKOVÁ - HLADKÝ - PELIKÁN, 635.

67 Sometimes also called The Bosnian-Croat Federation. 
was formed, ${ }^{68}$ which changed the balance of forces on the warring sides and thus ended military predominance of Republika Srpska in Bosnia and Herzegovina, as it still controlled more than two thirds of its territory. In April 1994, a plan was presented to the Contact Group, consisting of representatives from the USA, Russia, Great Britain, France and Germany. This plan was also rejected, however, it proposed the division of Bosnia and Herzegovina between the Serb Republic and the Federation of Bosnia and Herzegovina. ${ }^{69} \mathrm{~A}$ four-month ceasefire in December 1994 was another success, though temporary, which had been arranged by Jimmy Carter, former U.S. president. ${ }^{70}$ The ceasefire was broken after three months, and all parties used it for further armament and other war preparations. ${ }^{71}$

\section{Unity among the Individual Parties in Conflict?}

As mentioned above, political leaders of all the nations and the warring sides involved did not act in agreement. Over time, there were quite sharpened relations between the Federal Republic of Yugoslavia and the Bosnian and Croatian Serbs, and the differences got even worse in its course..$^{72}$ Although Radovan Karadžić, even in 1991, declared clear support of Bosnian Serbs for Slobodan Milošević, President of Serbia, saying "if Yugoslavia is to be dissolved, we authorise Slobodan Milošević to act on our behalf." ${ }^{173}$ During the war, there were cardinal differences between the Federal Republic of Yugoslavia and the Republika Srpska with the refusal of Vance-Owen plan by the Republika Srpska being the fundamental problem in the relations, despite Miloševićs efforts to push through the modified version of the plan so that the sanctions imposed on the Federal Republic of Yugoslavia, whose impact strengthened the opposition, could be lifted. ${ }^{74}$ As for the Vance-Owen peace plan, there was no unity among Muslims either. Fikret Abdić, a member of the board of Bosnia and Herzegovina for SDA, got into arguments with the leaders of SDA, especially with Alija Izetbegović. He tried to make an agreement with the Croats and Serbs, and in 1993, he founded Autonomous Province of Western Bosnia with the capital in Velika Kladuša, which concluded a peace treaty with the Republika Srpska, after which he came into conflict with political leaders of Bosnian Muslims and had to face attacks by Army of Bosnia and Herzegovina subject to $\mathrm{BiH}$ presidium. ${ }^{75}$ In addition, the war became complicated even more in April 1993 when the first armed clashes between Bosnian Croat forces supported by Franjo Tudjman, and the Army of Bosnia and Herzegovina occurred. In a way, this period is characterized by Croats and Serbs becoming closer. ${ }^{76}$ It was a bloc featuring Croatia and

68 WAGEMAKER, Allard: Twisting Arms, Flexing Muscles: Diplomatic and Military Interaction on the Road to Dayton, in: The Western Balkans. A European Challenge on the Decennial of the Dayton Peace Agreement, BUFON, Milan - GOSAR, Anton - NURKOVIĆ, Safet - SANGUIN, André-Louis (eds.), Koper 2006, 232.

69 WALDEMBERG, 209.

70 lbidem, 175

71 ŠESTÁK - TEJCHMAN - HAVLÍKOVÁ - HLADKÝ - PELIKÁN, 638.

72 CASPERSEN, Nina: Belgrade, Pale, Knin: Kin-State Control over Rebellious Puppets?, in: Europe-Asia Studies, 59, 2007, 4, 622.

73 Ibidem, 626.

74 Ibidem, 634.

75 ŠESTÁK - TEJCHMAN - HAVLÍKOVÁ - HLADKÝ - PELIKÁN, 634.

76 Ibidem. 
Bosnian Croats that was the most compact group, which had resulted from the traditionally strong influence of Croatian HDZ on HDZ-BiH. ${ }^{77}$

\section{Preparations for Peace Negotiations in Dayton}

Although all the warring sides had long been convinced of victory as the only way of ending the conflict, in the U.S. a conviction was beginning to prevail that an active involvement and pressure on the warring sides were necessary for the sake of adopting a peaceful solution. American diplomacy, therefore, set up three aims so that a consensus should be reached and the relevant parties would agree to negotiate on a peace treaty. The first aim was to achieve changes in the balance of powers on the front, then to weaken the Bosnian Serbs' position by bombing, and to win the support of European states and Russia for further negotiations. ${ }^{78}$ In the middle of 1995 , there were significant shifts on the battlefield. While there was dominance of Bosnian and Croatian Serbs in the fights almost all the time, the situation totally changed after the ceasefire between Croats and Bosniaks had been declared. In August 1995, Croatia performed an extensive military operation called Storm (Oluja). ${ }^{79}$ Within five days, Croatian units gained control over almost the entire territory of Croatia, except eastern Slavonia and Baranja, which continued to be parts of the Republic of Serbian Krajina. ${ }^{80}$ Fights were then moved into western Bosnia, where Bosnian Serbs also lost some territories. The Army of Republika Srpska (The Bosnian Serb Army) was deployed in the east of Bosnia, following a defeat of Croatian Serbs, conquered safe areas of Srebrenica and Žepa, ${ }^{81}$ "where they killed almost eight thousand Bosnian Muslims." " 82 Violation of protection status and war crimes committed by the Army of Republika Srpska, especially in Srebrenica, together with massacre in Markale Market on 27 August 1995, prompted NATO to start Operation Deliberate Force, intervene and bomb the military positions of the Republika Srpska. The low efficiency or in some cases the discussion about possible failures of several UN missions such as mission in Somalia, Mozambique, Rwanda or Bosnia and Herzegovina let many analytics and UN experts to revise the UN peacekeeping system in order to reform UN peacekeeping missions. ${ }^{83}$ It has also impact on U.S. foreign policy to play much more active role. Between 28 August and 14 September 3,500 combat flights were made, ${ }^{84}$ and Republika Srpska also faced a counteroffensive by the Bosnia-Croat coalition. ${ }^{85} \mathrm{As}$ a result of all these military operations, $70 \%$ of the territory

77 ANDJELIĆ, 160.

78 KOVAČEVIĆ, 138.

79 This operation was preceded by a military action called Flash (Bljesak) in May 1994, in which Croatia managed to occupy a territory of Western Slavonia. After the two actions, Croatian Serbs left their homes on a mass scale. See PRTINA, Zahraniční a bezpečnostní..., 17.

80 KLEMENČIĆ, 207.

81 These zones were established by the UN Security Council on 26 April 1993. They were established in Sarajevo, Mostar, Goražde, Srebrenica, Žepa and Tuzla. They were not supposed to face attacks and, under UN auspices, it was a place of operation for UNPROFOR peacekeeper. See WALDEMBERG, 172.

82 KLEMENČIĆ, 206.

83 WAJSOVÁ, Šárka: Řešení konfliktu v mezinárodních vztazích, Plzeň 2011, 171.

84 GUSKOVA, Istorija Jugoslovenske krize (1990-2000) 2, 138.

85 ŠESTÁK - TEJCHMAN - HAVLÍKOVÁ - HLADKÝ - PELIKÁN, 638-640. 
of Bosnia and Herzegovina which used to be controlled by the Army of Republika Srpska shrunk to $50 \%$ in 1995. ${ }^{86}$ NATO intervention, military progress of both Croatia and the Army of Bosnia and Herzegovina and subsequent weakening of the positions of the Bosnian Serbs facilitate the adoption of a compromise peace agreement.

Ministers for Foreign Affairs of the Federal Republic of Yugoslavia, Croatia and Bosnia and Herzegovina were informed about central principles adopted by the Contact Group on 8 September 1995 in Geneva. The main issues included recognition of Bosnia and Herzegovina and its borders, establishment of two entities - the Federation of Bosnia and Herzegovina should comprise $51 \%$ of the territory and the Republika Srpska was granted $49 \%$ of the territory of Bosnia and Herzegovina, furthermore, the right of the Entities to keep parallel relations with the neighbouring states, and an obligation to respect human rights. ${ }^{87}$ For negotiations in Dayton, Richard Holbrooke demanded three conditions to be met from presidents of Serbia, Croatia and Bosnia and Herzegovina: "First, that each President come to the United States with full power to sign agreements, without further recourse to parliaments back home. Second, that they stay as long as necessary to reach agreement, without threatening to walk out, and third, that they not talk to the press or other outsiders." ${ }^{88}$ All three presidents were willing to agree with these demands. ${ }^{89}$ Absence of some leaders of the Republika Srpska, including its president Radovan Karadžić, was a major breakthrough for the negotiations. International Criminal Tribunal for the Former Yugoslavia, ICTY, brought charges against Ratko Mladić and Radovan Karadžić for war crimes, which became one of the main reasons for leaving the position for negotiating to the president of neighbouring Serbia, Slobodan Milošević..$^{90}$ Radovan Karadžić, as the negotiator for the Bosnian Serbs, was unacceptable for American diplomacy. Slobodan Milošević was the only person the U.S. negotiators were willing to cooperate with. ${ }^{91}$

The strategy to limit the number of chief negotiators to the main three for each warring sides proved very successful. There were different interests among the conflict parties as well as deep contradictions among the political representations, therefore the U.S. requirement limiting the number of chief negotiators and the requirement to ensure a strong mandate for negotiating reduced potential friction between particular representations. The position for negotiating of the presidents of Serbia, Bosnia and Herzegovina and Croatia were quite different. Živorad Kovačević considers the position of Alija Izetbegović as the strongest. Abroad, there was a good media image of Bosniaks, they were perceived as victims by the American public, and they received good support especially from Republicans and also from influential Muslim countries. ${ }^{92}$ For A. Izetbegović and the Party of Democratic Action keeping a unified Bosnia and Herzegovina with the strongest possible powers on

86 JOKSIMOVIĆ, 33.

87 Ibidem, 34.

88 HOLBROOKE, Richard: To End a War, New York 1998, 199-200.

89 Ibidem, 200.

90 PRTINA, Zahraniční a bezpečnostní..., 24.; JOKSIMOVIĆ, 33.

91 JOKSIMOVIĆ, 33.

92 KOVAČEVIĆ, 155. 
the central level was the highest priority. ${ }^{93}$ The position of Croatia was strong too, which stemmed from the fact that top priority of territorial integrity of Croatia, had been almost reached during the conflict. ${ }^{94}$ In relation to Bosnia and Herzegovina, the main objective was just to ensure influence on the territory inhabited by Bosnian Croats. It was Slobodan Milošević who had the weakest position of the main players. Bosnian and Croatian Serbs had experienced major territorial losses during the last months before negotiations, they had to face negative international public opinion as well as negative media image abroad. Slobodan Milošević was forced to make concessions due to sanctions imposed in 1992 which had had a long lasting impact on the Federal Republic of Yugoslavia. ${ }^{95}$ Federal Republic of Yugoslavia was also in international isolation, which resulted from its attitude to the issue of insisting on legal continuity with its "predecessor", Socialist Federal Republic of Yugoslavia. Therefore, FRY refused to apply for accessions into international organizations. It had a "sui generis" status in the United Nations which only allowed it a limited presence, and little influence on the functioning of the organization. Neither was FRY a member of other important organizations, such as the World Bank or the International Monetary Fund. ${ }^{96}$

\section{Negotiations in Dayton}

A crucial role during the negotiations was played by the delegation of the United States which was later criticized for providing not enough room for other ones. U.S. negotiators' strategy, according to Richard Holbrooke, "was both ambitious and simple. We would never have a better chance to end the war in Bosnia - and therefore we sought to address as many issues as possible in the final agreements. What was not negotiated at Dayton would not be negotiated later. We recognized that implementation would be at least as difficult as the negotiations themselves, but we rejected the minimalist theory that we should negotiate only those matters on which implementation would be relatively easy. Later we would be criticized for being overly ambitious, but the alterative would have been a 'small' agreement, not much more than a cease-fire - and an opportunity lost, perhaps forever." 97 The negotiations were very well prepared, and American negotiators paid a relatively high attention to the smallest details. ${ }^{98}$ The preparations for negotiations were much inspired by the negotiations between Menachem Begin and Anwar Sadat at Camp David in September 1878, which resulted in a remarkable shift in Egyptian-Israeli relations and which ended the conflict between the two countries. ${ }^{99}$ It was also decided that "Proximity talks" would be used for the negotiations representing "a diplomatic technique origination in Mideast negotiations held in the 1940s at the U.N., in which the mediator moves between the two

\footnotetext{
93 JOKSIMOVIĆ, 35.

94 KOVAČEVIĆ, 155

95 Ibidem, 155-156.

96 PRTINA, Zahraniční a bezpečnostní..., 36.

97 HOLBROOKE, 205.

98 Ibidem, 204.

99 Ibidem, 205.
} 
parties, who rarely meet one another face-to face." 100

Wright-Patterson Air Force Base in Dayton, Ohio, whose isolation helped eliminate possible external influences that could affect the negotiations, was chosen as the place for the main negotiations. ${ }^{101}$ Another effort was the need to eliminate influences of antagonism among members of the delegations. It was the ambivalent relationship between Franjo Tudjman and Alija Izetbegović that was rather well-known. The president of Bosnia and Herzegovina also tried to enforce Haris Silajdžić being absent during the most significant points of the negotiations. In contrast, Slobodan Milošević was not much willing to communicate with the representatives of the Bosnian Serbs at the meetings. ${ }^{102}$ Chief U.S. negotiator, Richard Holbrooke, knew all three presidents quite well and set the main approaches to all three delegations "in order to build harmonised text of the agreement to be signed, but the communication method with the delegation and the path to that text was different for every delegation, especially regarding the arguments used to get the agreement of the signatories." ${ }^{103}$ All three parties were guaranteed achievement of their main objectives in advance. The final agreement had to be primarily the result of a compromise and all parties were supposed to feel that there was no winner and there was no loser. ${ }^{104}$

Richard Holbrooke "promised Milošević Republika Srpska, which was a precedence in such an important international agreement, and reputation of a peacemaker if he gave in on the other side, he promised Tudjman a peaceful gain of the regions of Srem and east Slavonia and reintegration of whole Croatia, he promised Izetbegović an integral and uniform state of Bosnia and Herzegovina, which would later appear on the international political scene as a sovereign and independent state." 105 Eventually, the timing for handover of Eastern Slavonia to Croatia appeared to be rather problematic issues of the negotiations. Franjo Tudjman insisted that the handover took place within one year, whereas Slobodan Milošević required three years to do so. ${ }^{106}$ The most problematic point of the talks was the question of the precise division of Bosnia and Herzegovina between the two entities. U.S. negotiators insisted on strict compliance with the distribution of the country in a ratio of $51: 49 \% .{ }^{107}$ During the talks, Milošević made an unexpected proposal and offered The Bosnian-Croat federation parts of the capital of Sarajevo, formerly claimed by the Bosnian Serbs, which in-

100 Ibidem, 205.

101 ŠESTÁK - TEJCHMAN - HAVLÍKOVA - HLADKÝ - PELIKÁN, 641.

102 KOVAČEVIĆ, 159. Relations among the members of the negotiating teams of the opposing parties were taken into consideration at various occasions. As reported by Živorad Kovačević, for example in a restaurant in the officers' club, particular people were never seated together, for example Silajdžić with Izetbegović, Milošević with Momčilo Krajišnik, the Chairman of the Parliament of Republika Srpska, or Frajnjo Tujman with Krešimir Zubak. See KOVAČEVIĆ, 162.

103 CIKOTIĆ, Selmo: Dayton's Modification or Upgrading?, in: The Western Balkans. A European Challenge on the Decennial of the Dayton Peace Agreement, BUFON, Milan - GOSAR, Anton - NURKOVIĆ,

Safet - SANGUIN, André-Louis (eds.), Koper 2006, 287.

104 HLADKÝ, Ladislav: Dwanaście lat po Dayton - rzeczywistość i iluzje, in: Europejski protektorat? Bośnia i Hercegowina w perspektywie środkowoeuropejskiej, Mateusz GNIAZDOWSKI (ed.), Warszawa 2008, s. 17.

105 CIKOTIĆ, 287.

106 KOVAČEVIĆ, 163.

107 ŠESTÁK - TEJCHMAN - HAVLÍKOVA - HLADKÝ - PELIKÁN, 641. 
creased the proportion of this part of Bosnia and Herzegovina at 55\%. Slobodan Milošević demanded territorial compensations, having no special claims regarding the territories that Republika Srpska was supposed to receive. Haris Silajdžić offered Serbian delegation a part of a territory south of the town of Kljuć, which was held by Croats. Tudjman was not willing to agree with the exchange. Alija Izetbegović was not willing to offer any other territory. Eventually, under pressure from the U.S. negotiators he was willing to retreat. The biggest concession was done by Slobodan Milošević at last, who was willing to hand over a territory around the Brčko under the temporary administration, and leave the decision on its future status on the arbitration. ${ }^{108}$ The concessions that Slobodan Milošević was willing to do surprised not only the representatives of the Serb Republic, who were in isolation during Dayton negotiations, ${ }^{109}$ but also the American negotiators. A logical explanation seems to be that by means of the cession of the entire territory of Sarajevo to Federation of Bosnia and Herzegovina, Milošević wanted to weaken the position of Radovan Karadžić and, at the same time, strengthen Bosnian Serb politicians from other parts of Bosnia, especially from the Western one. ${ }^{110}$ For making the peace agreement, Milošević was motivated primarily by economic sanctions ${ }^{111}$ and the main reason for weakening the position of Radovan Karadžić was dissension between the Federal Republic of Yugoslavia and the Republic of Serbia after 1993, and especially frequent cooperation of Karadzic's SDS with Yugoslav opposition parties. ${ }^{112}$ On 21 November, Dayton Peace Agreement was concluded and it was signed in Paris on 14 December 1994. ${ }^{113}$

\section{Significance of the Dayton Peace Agreement}

The Dayton peace agreement and the end of fights in 1995 were undoubtedly a significant success of American diplomacy in the first place. The conflict in the former Yugoslavia was certainly the biggest one on the European continent since the end of WW2. The conflict changed ethnic boundaries, there were about 2 million refugees and 200 thousand people were killed only in Bosnia and Herzegovina at the time of signing the agreement. ${ }^{114}$ When concluding the Dayton Peace Agreement "actual use of force provided a firm base for mediation, negotiation, and implementation." ${ }^{115}$ The agreement was unable to fulfil quite an ambitious plan of U.S. negotiators to approve a peace plan that would bring solutions of the most controversial issues between the particular parties in the conflict. According to Ladislav Hladký, the Dayton Peace Agreement is "actually a very complicated document with internal contradictions". ${ }^{116}$ The compromise reached maintaining the integrity of Bos-

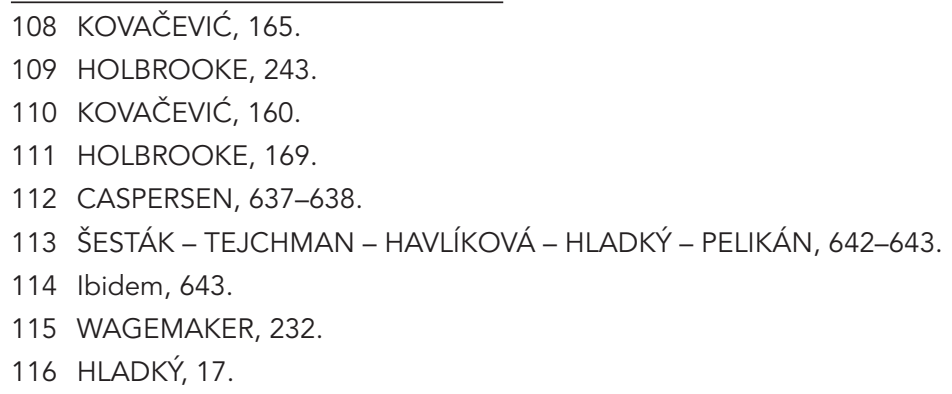


nia and Herzegovina, which was supposed to be headed by a three-member presidency. At the same time, its territory was divided between two entities, Republika Srpska and the Federation of Bosnia and Herzegovina, which is further divided into ten cantons. ${ }^{117}$ In accordance with the agreements, there were supposed to be relatively weak central institutions and the agreement introduced "power-sharing arrangements between the three national groups"118 The internal organization of Bosnia and Herzegovina is therefore quite complicated, the decision-making process is rather slow, and the political system could not do without the intervention of the Office of the High Representative, whose powers were increased significantly in $1997 .{ }^{119}$

Post-conflict organization was supposed to be guaranteed by IFOR (Implementation Forces) units, acting under the auspices of NATO ${ }^{120}$, which also played an important role in keeping peace in Bosnia and Herzegovina. A demand for safe return of refugees to their homes was also anticipated in Dayton Peace Agreement. ${ }^{121}$ Although American diplomats and politicians "believed in a rapid stabilization of the peacetime situation and also of the imposed political system,"122 the people who signed it, later boycotted its implementation. ${ }^{123}$ Attitudes of neighbouring countries towards Bosnia and Herzegovina were quite problematic. Franjo Tudjman used HDZ-BiH to put pressure on political elites of Bosnia and Herzegovina and he was convinced that the internal organization of Bosnia and Herzegovina would lead to its breakup, so he considered the division of powers according to the Dayton Peace Agreement as a temporary, ${ }^{124}$ and its federal parliament ratified the Dayton Peace Agreement only in 2002, two years after the fall of the Milošević regime. ${ }^{125}$

\section{Conclusion}

The breakup of Yugoslavia led to a prolonged military conflict which destabilized the particular states involved over a long period of time. To the greatest extent, fights affected ethnically heterogeneous Bosnia and Herzegovina, which suffered heavily from destabilizing effects. Over a long time, U.S. foreign policy lacked clear and distinct strategy not only towards the Yugoslav crisis but towards the war, too. During the escalation of the conflict in the Balkans, international attention was focused on the Gulf region, where the United States had more significant interests. Together with the collapse of the bipolar world, the

117 International arbitration in late 1999 and in 2000 decided on the specific status of Brčko District, which belongs to both entities. See KASUM, Damir: Vývoj politického systému Bosny a Hercegoviny po Daytonu a jeho současná podoba, in: Středoevropské politické studie - Central European Political Studies Review, 8, 2006, 2-3, 336.

118 WAGEMAKER, 228.

119 KASUM, 336.

120 PRTINA, Zahraniční a bezpečnostní..., 25.

121 WAGEMAKER, 228.

122 HLADKÝ, 17.

123 BAUEROVÁ, Helena: Bosna a Hercegovina jako konsociační demokracie. Analýza aplikovatelnosti Lijphartova modelu. Praha 2013, 39.

124 HLADKÝ, 18.

125 PRTINA, Zahraniční a bezpečnostní..., 25. 
USA stood in front of a new challenge of redefining its foreign policy. Around 1989, the Socialist Federal Republic of Yugoslavia was one of the biggest beneficiaries of the international order. After the collapse of the Soviet bloc, its position got worse considerably. The USA imposed much greater emphasis on political freedom, democratic norms and respect for human rights. In this context, the U.S. demanded fulfilment of these norms by political elites in Yugoslavia. Eventually, the United States left initiative to resolve the Yugoslav crisis of the early 90s to the European Community, which suggests that, after the end of the Cold War, Yugoslavia became an unimportant participant in international relations busy with their own disputes. However, the European Community had only a limited capacity to solve the crisis in the former Yugoslavia. With the declaration of independence of Bosnia and Herzegovina, the United States reviewed their attitude and tried to gain a wider international recognition for Bosnia and Herzegovina. Although in the early years of the war in Bosnia and Herzegovina U.S. officials did not accept direct military intervention of the United States, given the fact that the highest costs were to be carried by the United States, because the European Community or later the European Union did not have the same capabilities for a military operation. The intensity of American action changed a lot. The USA managed to persuade Slobodan Milošević, Alija Izetbegović, and Franjo Tudjman to conclude a peace agreement which was designed so that none of the parties felt either victory or defeat. All the parties were guaranteed to reach their main objectives as well. Territorial integrity for both Croatia and Bosnia and Herzegovina was ensured. The Federal Republic of Yugoslavia reached the alleviation of economic sanctions. Within the political system of Bosnia and Herzegovina two entities with a rather high degree of autonomy were established. Implementation of the peace agreements was the most difficult and most complicated just in Bosnia and Herzegovina. On the one hand, a peace agreement that ended the long-lasting conflict was concluded, on the other hand, no stable political environment for independent development of Bosnia and Herzegovina was established. There was also a very complicated attitude of Slobodan Milošević and Franjo Tudjman who considered the organization of neighbouring Bosnia and Herzegovina a temporary state and were still trying to affect the development in this country. Their beliefs were strengthened by their own positions they had been assigned for the negotiations in Dayton. They both were in a position that allowed them to assert their own interests at the expense of the Bosnian Serbs or Croats. Until now, coexistence of the particular constituent nations has been very problematic and the development in the last few years shows that Bosnia and Herzegovina was not able to do without intervention of the international community, particularly the Office of the High Representative.

\section{Abstract}

Article deals with the changes of the foreign policy of the United States of America after the end of the Cold War towards disintegrating Socialist Federal Republic of Yugoslavia. Article tries to explain the main reasons which influenced the process of disintegration of Yugoslavia and led to the war between 1991 and 1995. The main attention is paid to the main reasons of changes of the U.S. role and involvement in the conflict. It also evaluates 
the main goals and strategies of Serbs, Croats and Bosniaks. The last part deals with the negotiations in Dayton in 1995, which ended one of the most important conflicts after 1945 and it evaluates the significance of Dayton Peace Accord.

\section{Keywords}

Yugoslavia, ethnic conflict, war, negotiations, foreign policy, peace, conflict resolution

\section{References}

ANDJELIĆ, Neden: Bosnia - Herzegovina. The End of a Legacy, London 2003.

BAUEROVÁ, Helena: Bosna a Hercegovina jako konsociační demokracie. Analýza aplikovatelnosti Lijphartova modelu. Praha 2013.

BUJDWID-KUREK, Ewa: Państwa pojugosłowiańskie. Szkice politologiczne. Kraków 2008.

CASPERSEN, Nina: Belgrade, Pale, Knin: Kin-State Control over Rebellious Puppets?, in: Europe-Asia Studies, 59, 2007, 4, 621-641.

CIKOTIĆ, Selmo: Dayton's Modification or Upgrading?, in: The Western Balkans. A European Challenge on the Decennial of the Dayton Peace Agreement, BUFON, Milan - GOSAR, Anton - NURKOVIĆ, Safet - SANGUIN, André-Louis (eds.), Koper 2006, 285-298.

GOATI, Vladimir, et al.: Jugoslavija na prekretnici. Od monizma do gradjanskog rata, Beograd 1991.

GOMPERT, David: How to Defeat Serbia, in: Foreign Affairs, 73, 1994, 4, 30-47.

GUSKOVA, Jelena: Istorija jugoslovenske krize (1990-2000) 1, Beograd 2003.

GUSKOVA, Jelena: Istorija jugoslovenske krize (1990-2000) 2, Beograd 2003.

HLADKÝ, Ladislav: Dwanaście lat po Dayton - rzeczywistość i iluzje, in: Europejski protektorat? Bośnia i Hercegowina w perspektywie środkowoeuropejskiej, GNIAZDOWSKI, Mateusz (ed.), Warszawa 2008, 17-32.

HOLBROOKE, Richard: To End a War, New York 1998.

JOKSIMOVIĆ, Aleksandra: Srbija i SAD. Bilateralni odnosi u tranziciji. Beograd 2007.

KASUM, Damir: Vývoj politického systému Bosny a Hercegoviny po Daytonu a jeho současná podoba, in: Středoevropské politické studie - Central European Political Studies Review, 8, 2006, 2-3, 327-341.

KLEMENČIĆ, Matjaž: Response of the International Community to the Yugoslav Crisis 1989-1995: Selected Themes, in: The Western Balkans. A European Challenge on the Decennial of the Dayton Peace Agreement, BUFON, Milan - GOSAR, Anton - NURKOVIC, Safet - SANGUIN, André-Louis (eds.), Koper 2006, 191-212.

KOVAČEVIĆ, Živorad: Amerika i raspad Jugoslavije, Beograd 2007.

ОБРАДОВИЋ, Жарко: Мањине на Балкану, Београд 2002.

PIRJEVEC, Jože: Jugoslávie 1918-1992 - Vznik, vývoj a rozpad Karadjordjevićovy a Titovy Jugoslávie. Praha 2000.

PRTINA, Srdjan: Zahraniční a bezpečnostní politika Srbska a Černé Hory, in: 
Zahraniční a bezpečnostní politika vybraných zemí Balkánu, STÝSKALÍKOVÁ, Věra SMEJKAL, Hubert (eds.), Brno 2004, 12-57.

PRTINA, Srdjan: Přeměna Jugoslávské lidové armády na armádu Srbskou, in: Mezinárodní vztahy, 40, 2005, 4, 50-78.

RYCHLÍK Jan - KOUBA, Miroslav: Dějiny Makedonie, Praha 2003.

THOMAS, Robert: Serbia under Milošević. Politics in the 1990s. London 2000.

ŠESTÁK, Miroslav - TEJCHMAN, Miroslav - HAVLÍKOVA, Lubomíra - HLADKÝ, Ladislav PELIKÁN, Jan: Dějiny jihoslovanských zemí, Praha 1998.

United Nations, Security Council Resolution 781, online: http://www.un.org/en/ga/search/ view_doc.asp?symbol=S/RES/781(1992).

VLADISAVLJEVIĆ, Nebojša: Serbia's Antibureaucratic Revolution. Milošević, the Fall of Communism and Nationalist Mobilization, New York 2008.

VOMLELA, Lukáš: Svaz komunistů Srbska v procesu tranzice a dezintegrace Jugoslávie, Opava 2013.

WAGEMAKER, Allard: Twisting Arms, Flexing Muscles: Diplomatic and Military Interaction on the Road to Dayton, in: The Western Balkans. A European Challenge on the Decennial of the Dayton Peace Agreement, BUFON, Milan - GOSAR, Anton - NURKOVIĆ, Safet SANGUIN, André-Louis (eds.), Koper 2006, 213-236.

WAJSOVÁ, Šárka: Řešení konfliktu v mezinárodních vztazích. Plzeň 2011.

WALDEMBERG, Marek: Rozbicie Jugosławii. Jugosławskie lustro międzynarodowej polityki. Warszawa 2005.

WOODWARD, Susan L.: Balkan Tragedy. Chao and Dissolution after the Cold War, Washington 1994.

ZACHARIAS, Michał Jerzy: Komunizm, federacja, Nacjonalizmy: System władzy w Jugosławii 1943-1991. Powstanie - prezekształcenia - rozkład, Warzawa 2003.

ZIMMERMANN, Warren: The Last Ambassador. A Memoir of the Collapse of Yugoslavia, in: Foreign Affairs 74, 1995, 2, 2-20. 